\title{
Genade als literair motief in de Confessiones
}

\author{
Anthony Dupont en Matthias Smalbrugge
}

NTT 72 (1): 3-17

DOI: 10.5117/NTT2018.1.DUPO

\begin{abstract}
The linguistic turn revealed the hermeneutic interaction between content/ ideas and their literary form/structure. Recently, this insight has been applied to the oeuvre of Augustine of Hippo - his Confessiones in particular, though conclusions in recent research very much differ. This is why, in the current article, we adopt different approaches based on this linguistic turn. Our focus is in particular on the so-called Ostia-ecstasy in Confessiones $\mathrm{IX}, 10,23$, a scene in which we try to distinguish more clearly the role of grace. By investigating how literary/philosophical structural elements (for instance, the motive of three gardens, the narrative of separation, the Neoplatonist scheme of ascent of the soul) co-determine Augustine's (early) reflections about grace, we show that the latter actually escape any attempt to unilaterally interpret them.
\end{abstract}

\section{De linguistic turn}

Eén van de belangrijkste vragen bij literaire teksten als die van Augustinus van Hippo (354-430) is de vraag naar de vormgeving van de thema's die de auteur behandelt. Die vragen figureren reeds lang in de literatuur, toch gaf de linguisitic turn er een nieuwe impuls aan. Wat is eigenlijk Augustinus' hermeneutiek, wat is de rol van de literaire vorm en structuur van zijn werk? ${ }^{1}$

1 Een heldere inleiding hierop is te vinden bij E.A. Clark, History, Theory, Text. Historians and the Linguistic Turn, Harvard 2004. In haar woorden: 'Have we then no "real" Macrina or Monica in these representations (De anima et resurrectione; Confessiones)? We are reduced to this option only if we imagine that ancient treatises transparently "refer" to the events 
De ontwikkeling van zijn genadeleer kan worden bestudeerd, ${ }^{2}$ maar binnen dat thema kan ook nadrukkelijk onderzocht worden hoe hij zijn opvattingen in een bepaalde structuur giet. Die verwoording en structuur kunnen als het ware een tweede laag van de inhoud zijn. ${ }^{3}$ Dit leidt weer tot een geheel ander beeld van de kerkvader. ${ }^{4}$ Dat is in lijn met Augustinus' eigen aandacht voor taal als teken. ${ }^{5}$ Anders gezegd, we kunnen het hebben over de primaire boodschap, maar we kunnen het ook hebben over de structuur van de boodschap, de hermeneutiek, en de vorm die deze aan Augustinus' theologie verleent. ${ }^{6}$

Het debat over de hermeneutiek in het werk van de bisschop van Hippo toont een fascinerende ontwikkeling. Neem de Confessiones. Er kan op literaire gronden worden betoogd dat de Confessiones protreptische literatuur zijn, bedoeld om de lezers aan te sporen zich ook te bekeren. ${ }^{7} \mathrm{Er}$ kan met evenveel recht worden gesteld dat het een boek is dat als bedoeling heeft om Augustinus' levensloop in sociaal opzicht acceptabel te maken: de manicheeër die christen is geworden, of de dolende waarheidszoeker die in het christendom de ware weg heeft gevonden. ${ }^{8}$ Tussen beide opvattingen is een groot verschil. Toch ontlenen beide invalshoeken sterke argumenten aan het analyseren van de taal die Augustinus gebruikt, de scopus die de auteur hanteert, de topoi waar hij op terugvalt, vaak zonder dat de lezer (en/ of auteur) zich daarvan volledig bewust is. Anders gezegd, de linguistic turn beoogt ook een structurele bewustwording van niveaus die functioneren als onbewuste kaders van onze interpretatie.

and people they depict. But if, with literary theorists, we abandon that view, we still have "lives" of Macrina and of Monica - but ones moulded by literary representation. Moreover, their textual representations hint at "life outside the text", namely (male) Christian writers' desire to stress that Christianity is open to all.' (181)

2 L. Karfíková, Grace and Will according to Augustine, Leiden/Boston 2012; T. Nisula, Augustine and the functions of concupiscence, Leiden/Boston 2012.

3 M. Smalbrugge, Beauty and Grace in Augustine (Studia Patristica 44-49), Leuven 2010, 9-13.

4 K. Pollmann, 'Alium sub nomine meo: Augustine between his own Self-reception and his Later Reception', Zeitschrift für Antikes Christentum 14 (2010), 409-24.

5 Ph. Carey, Outward Signs: The Powerlessness of External Things in Augustine's Thought, Oxford 2008.

6 T. Toom, Augustine's Hermeneutics. The Science of the Divinely Given Signs, in, Patristic Theories of Biblical Interpretation. The Latin Fathers, Cambridge 2016, 77-108.

7 A. Kotzé, Augustine's Confessions: Communicative Purpose and Audience, Leiden 2004.

8 J.J. O'Donnell, Augustine. A New Biography, New York 2005. Als het belijdeniskarakter van de Confessiones wordt 'ontmaskerd' is de terechte kritiek dat dan nog steeds de vraag blijft naar wat dan wel de theologische coherentie van het boek bepaalt. Zie M. Burcht Pranger, Eternity's Ennui. Temporality, Perseverance and Voice in Augustine and Western Literature, Leiden/Boston 2010, 14-18. 
Nogmaals de Confessiones. De lezer wordt getroffen door het intieme karakter van het boek. Het begint en eindigt met een gebed en het lijkt alsof Augustinus slechts de dialoog op schrift stelt die hij met zijn God voert. Het lijkt bijna een spiritueel zelfportret, enkel bestemd voor Augustinus' eigen ogen. Niettemin, de auteur had de intentie het werk te publiceren, ondanks zijn persoonlijke twijfels. Of zijn dat juist voorgewende twijfels, bedoeld om het 'authentieke' karakter van de Confessiones te onderstrepen? ${ }^{9}$ Als schrijver wist hij immers dat een verzinsel soms echter overkomt dan de waarheid. Dan is de literaire kunstgreep - onzentwege pia fraus - toch zeker geoorloofd met het oog op een hoger doel? Wat liet hij weg in dit spirituele zelfportret, wat haalde hij naar voren? Een gelaagde tekst kortom en elke constatering dat de intentie van een auteur een gelaagde kan zijn, staat haaks op unificatiemodellen, die beogen een continuüm in het werk van een auteur aan te tonen, dan wel een dergelijk continuüm te creëren. ${ }^{10}$ Hiermee komt de rol van de interpreet scherp naar voren en er ontstaat een dubbele focus. Enerzijds op het werk van de auteur en de gelaagdheid daarvan, anderzijds op de rol van de lezer. ${ }^{11}$ Het subject verandert zelf in de bestudering van het object, maar zal dat object ook weer zien veranderen in zijn ogen. De verhouding subject-object is dynamisch.

Vanuit het besef van Augustinus' gelaagd schrijverschap, en de belangrijke hermeneutische taak van de lezer, hebben wij er uitdrukkelijk voor gekozen om dit artikel met twee auteurs te schrijven. Als illustratie en als toetsing van bovenstaand inzicht zullen wij - met elk een uiteenlopende visie op de (eventuele) ontwikkeling in Augustinus' genade-denken een beroemde passage uit de Confessiones lezen, de extase van Ostia uit Confessiones IX,10,23 $3^{12}$ - een tekst die echter veelal niet tegen de achtergrond van Augustinus' genadeleer wordt gelezen; ten onrechte, zoals wij, elk op onze eigen wijze, zullen betogen. Leidende vraag hierbij is hoe we de rol van de genade kunnen schetsen. Is genade de vertaling van de absolute prioriteit van Gods handelen ten opzichte van het menselijke handelen? Dus het leitmotiv in het hele oeuvre van de kerkvader? Of is het veeleer het perspectivische verdwijnpunt van de schrijver. Een verdwijnpunt dat hij construeert door een werkelijkheid te poneren die aan gene zijde van schuld en genade ligt en waar het subject zijn eigen rol verliest?

9 Zie Conf. II,3,5; X,2,2-5,7.

10 Het bekendste voorbeeld daarvan is C. Harrison, Rethinking Augustine's Early Theology: an Argument for Continuity, Oxford 2006.

11 M. Foucault, l'Herméneutique du sujet. Cours au Collège de France, 1981-1982, Parijs 2001.

12 Voor de bespreking van Confessiones IX, 10/23-10/26, zie onder andere: K.J. Coyle, 'In Praise of Monica: A Note on the Ostia Experience of Confessions IX', Augustinian Studies 


\section{De Ostia-extase}

\section{Drievoudige bekering(en) - Dupont}

Wat vertelt het verhaal, opgetekend in boek IX,10,23-12,29 van de Confessiones? Moeder en pas gedoopte zoon bevinden zich in Ostia, de haven van Rome, in afwachting van hun overtocht terug naar Afrika. Dit is de tekst: 13

De dag was op handen dat zij uit dit leven zou heengaan. U wist van die dag, maar wij niet. Op een dag - en ik geloof dat $u$ daar op uw verborgen manier voor had gezorgd - stonden zij en ik alleen voor een raam met uitzicht op de binnentuin van het huis waar wij woonden, in Ostia aan de Tiber. Na een lange en vermoeiende reis hadden we ons daar teruggetrokken uit de drukte, om kracht op te doen voor de overtocht. We hadden daar samen een heel fijn gesprek. We vergaten wat voorbij was en richtten ons op wat voor ons lag. In tegenwoordigheid van de Waarheid, die u bent, vroegen wij ons af hoe we ons het eeuwige leven van de heiligen moesten denken, dat geen oog heeft gezien, geen oor heeft gehoord en in geen mensenhart is opgekomen. ${ }^{14}$ Maar de mond van ons hart stond wijd open naar de verheven stroom uit uw bron, de bron van leven die bij u is. Daardoor besproeid, voor zover we daar ontvankelijk voor waren, richtten we onze gedachten toch op zoiets groots. (IX,10,23)

Moeder en zoon staan aan een raam met uitzicht op de binnentuin en beleven daar een spiritueel hoogtepunt terwijl ze met elkaar praten. Dat Augustinus uitdrukkelijk vermeldt dat deze ervaring plaatsvond met zicht op een binnentuin, wijst op een literair motief binnen de Confessiones. In de Confessiones zijn tuinen een belangrijke locatie. ${ }^{15} \mathrm{Zo}$ is er de boomgaard in Thagaste waar de jonge Augustinus en zijn kameraden de perenbomen

13 (1982), 87-96. R. Dobbins, Silence and Speech in the Ostia Experience: The Case of fons vitae' (Studia Patristica 38), Leuven 2001, 64-69. D. Hattrup, 'Confessiones IX: Die Mystik von Cassiciacum und Ostia', in N. Fischer, C. Mayer (red.), Die Confessiones des Augustinus von Hippo. Einführung und Interpretationen zu den dreizehn Büchern, Freiburg/Basel 1998, 389443. A. Mandouze, L'extase d'Ostie. Possibilités et limites de la méthode des parallèles textuels (Augustinus Magister 1), Parijs 1954, 67-84. J.M. Quinn, 'Mysticism in the Confessiones: Four Passages Reconsidered', in F. Van Fleteren (red.), Collectanea Augustiniana - Augustine Mystic and Mystagogue, Washington D.C./Baltimore 1994, 251-286.

13 In deze bijdrage wordt de vertaling van de Confessiones door W. Sleddens gebruikt: Aurelius Augustinus, Belijdenissen, Budel 2009.

141 Korintiërs 2:9.

15 G. Tavard, Les jardins de Saint Augustin. Lecture des Confessions, Montréal 1988. 
beroven (boek II). Deze boomgaard symboliseert voor Augustinus de Bijbelse paradijstuin, terwijl de perendiefstal staat voor de val van de mens. Genesis verhaalt dat Adam en Eva hun oorspronkelijke onschuld, goedheid en vrijheid verloren in de paradijstuin. Augustinus bekent dat hij door het stelen van de peren, waarvoor hij zelf geen enkele reden kon opgeven, koos voor het kwade omwille van het kwade zelf. In deze eerste tuin 'valt' Augustinus, verwijdert hij zich van God. Hij keert zich af van God en keert zich toe naar aardse verlokkingen - de concupiscentia en delectationes waarvan verderop nog sprake is. Een tweede tuin bevindt zich in Milaan (boek VIII). Augustinus is intellectueel tot het besef gekomen dat waarheid enkel binnen het christendom kan gevonden worden, maar hij kan er zichzelf niet toe brengen zich daadwerkelijk te bekeren. Vertwijfeld zit hij onder een vijgenboom, tot hij een ongeïdentificeerde stem hoort roepen: 'tolle, lege - neem en lees.' Als hij vervolgens Romeinen 13:13-14 leest maakt deze oproep van Paulus tot bekering en onthechting hem zo vastberaden dat hij zijn oude leven opgeeft en zich laat dopen. De tweede tuin is dus de tuin van de ommekeer en terugkeer. De binnentuin in Ostia is de derde tuin. Het is niet zonder betekenis dat dit een binnentuin is. Deze tuin symboliseert immers de inkeer. In deze inkeer in het eigen binnenste zal Augustinus in aanraking met God komen, als een voorproeven van het hemelse leven. In hun hart keren Augustinus en zijn moeder zich in zichzelf terug, overstijgen ze zichzelf en daar ontdekken ze God, het hogere. De drie tuinen duiden de drie periodes aan in het leven van Augustinus, het leven van elke mens: wegkeren/afkeren, omkeren/bekeren, inkeren/overstijgen. Augustinus en Monica bevonden zich in Ostia bovendien niet in de binnentuin, maar keken er via een raam naar. Het is met andere woorden een eschatologische tuin: de hemelse tuin, waarop we hier in dit leven misschien wel al een blik kunnen werpen, maar waarin we nog niet rondwandelen.

\section{Het verlatingsmotief en het Neoplatoons gedachtegoed - Smalbrugge}

Er is ook een andere duiding mogelijk. Een duiding die gestoeld is op de Neoplatoonse achtergrond van Augustinus. De drievoudige bekeringsbeweging is immers een klassiek Neoplatoons patroon: een zich afkeren van de fysieke werkelijkheid, dan een wending naar het innerlijk, ten slotte een loslaten van het discursieve denken. Het geheel behelst een beschrijving van de terugkeer naar God. Op die innerlijke reis worden eerst de genietingen van het vlees losgelaten, de delectationes. Vervolgens is er de reis langs 
alle zintuigelijke gewaarwordingen, het te boven gaan van het denken en ten slotte het raken aan het zijn zelf: dat wat geheel zichzelf is: id ipsum. Dan zal er sprake zijn van een iucunditas, een werkelijke vreugde van het beleven van het zijn.

Hoe vult Augustinus dit Neoplatoonse schema dan in? Door te verwijzen naar momenten van verlating en weer eenwording. Hij opent de passage met de vermelding dat: 'de dag was op handen dat zij [Monica] uit dit leven zou heengaan'. Dus dat zij hem zou verlaten, een directe spiegelverwijzing naar het moment dat hijzelf uit Monica's leven verdween toen hij stiekem scheep ging naar Rome en in de haven van Carthago zijn moeder achterliet, zoals hij verhaalt in Confessiones V,8,14-9,17. Maar op haar beurt verwees die scène weer naar Vergilius en naar het dramatische achterlaten van Dido door Aeneas, een verhaal waarvan Augustinus in de Confessiones vermeldt dat het hem op school diep had getroffen. ${ }^{16}$ De zinspeling op deze dubbele 'verlatingsscène' maakt nu juist deze passage van de Ostia-extase, als vervolg op de verlatingsscène, moeilijk te duiden. Wat des te meer geldt daar Augustinus zelf intussen zijn eigen geliefde, op aandringen nu juist van Monica, ook had verlaten. Hij had met haar gebroken en zij was teruggekeerd naar Afrika. Als nu deze verwijzingen naar Dido en Aeneas als een verborgen laag de setting vormen van het relaas van de extase, hoe verhoudt zich dan die setting ten opzichte van de inhoud? Het minste dat we ervan kunnen zeggen, is dat de originele scène, die van verlating, nu is getransformeerd tot een setting waarin eenheid en geen scheiding wordt beleefd. De eerdere scènes (Augustinus die zijn moeder achterlaat, Aeneas die Dido verlaat) worden met een tegenbeeld als het ware verheven tot een ander niveau.

Hoe verweeft Augustinus deze klassieke verwijzingen nu met het Neoplatoons gedachtegoed? Allereerst er is sprake van een zich afkeren van de materiële werkelijkheid en een ingaan in het innerlijk. Het patroon van deze aversio (afkering) is min of meer een topos, ${ }^{17}$ die teruggaat op Plato en Plotinus, maar bijvoorbeeld ook bij de Stoa voorkomt, ${ }^{18}$ zij het ook al in een meer moreel kader. ${ }^{19}$ Ten tweede is er de beschrijving van de extase zelf. Ten slotte is er de beschrijving van de reflectie over deze extase, de

16 Conf. I,13,21.

17 I. Ramelli, 'The Divine as Inaccessible Object of Knowledge in Ancient Platonism: A Common Philosophical Pattern across Religious Traditions', Journal of the History of Ideas 75 (2014), 167-188.

18 M. Frede, A Free Will. Origins of the Notion in Ancient Thought, Berkeley 2011.

19 T. Brennan, The Stoic Life: Emotions, Duties and Fate, Oxford 2005, in het bijzonder hoofdstuk II,7, 'Impulses and Emotions', 82-114. 
terugkeer naar het redelijke discours. Wat echter met name frappeert, is het feit dat Augustinus in elk van de drie delen het werkwoord 'aanraken' (attingere) gebruikt: het aanraken van het land van overvloed, het aanraken van de wijsheid en het aanraken van de wijsheid met ons verstand. ${ }^{20}$ De bestemming, de gepredestineerde orde, kunnen we even raken. Zelfs met het discursieve denken! De kenmogelijkheid schuilt in het aanraken. Dat is opvallend omdat we soortgelijke beschrijvingen bij Plotinus terugvinden. Bijvoorbeeld aan het eind van Enneade $\mathrm{V}, 3,{ }^{21}$ eveneens met datzelfde werkwoord 'aanraken' (eph-hapsastai). Wat niet noodzakelijkerwijs impliceert dat Augustinus deze Enneade heeft gelezen, ${ }^{22}$ maar wel dat dit soort beschrijvingen niet uniek is. Het slot van deze Enneade leest als volgt:

Want hoewel de ziel zweeft over alle ware dingen, ook de ware waaraan wij deelhebben, toch vlucht ze in zichzelf, als iemand erover wil spreken en denken; want ons discursieve denken moet, wil het iets zeggen, de dingen na elkaar nemen; want zo komt er een gedetailleerde beschrijving. Maar hoe kan er in het volledig enkelvoudige sprake zijn van een gedetailleerde beschrijving? Wel, daar zal ook een aftastend denken voldoende zijn. En men moet maar geloven dat men dan aanschouwd heeft, wanneer de ziel 'plotseling' het licht opvangt. Want dat - namelijk het Ene - komt van het licht en dat is hijzelf... Maar als ze het licht ontvangt, bezit ze wat ze najoeg en dat is het ware doel voor een ziel om dat licht aan te raken en daardoor het licht te aanschouwen, niet met het licht van iets anders, maar met juist dat licht waardoor ze aanschouwt. ${ }^{23}$

Wat duidelijk lijkt te zijn, is dat ook bij Plotinus het sterke besef aanwezig is dat je het licht slechts even kunt aanraken, dat er een kort moment is waarin het schouwen hetzelfde is als het licht-zijn waarbij je ziet. Vervolgens, dat er dan weer sprake is van een terugkeer naar het discursieve denken. Maar

20 Resp. in Conf. IX,10,24-25: attingere regionem ubertatis; attingere sapientiam; attingere rapida congitatione aeternam sapientiam.

21 D. O'Brien, 'Augustine at Ostia: A Common Misreading', in F. Karfik, E. Song (red.), Plato Revived: Essays on Ancient Platonism in Honour of Dominic J. O'Meara, Berlin/Boston 2013, 343-357, wijst uitdrukkelijk op de allusies op Enneade V,I,1O, de passage over stilte in de ziel. De verwijzing is belangrijk, evenwel niet noodzakelijk overtuigend omdat de auteur volstrekt niet ingaat op de Vorlage van deze scène en de beschrijving van de stilte door Augustinus daarmee isoleert van de context. Wel geeft het aan dat meerdere onderzoekers Plotinisch materiaal menen aan te treffen.

22 De strijd daarover is niet beslecht. Zie, J.P. Kenney, The Mysticism of Saint Augustine: Rereading the Confessions, London 2005; B. Dobell, Augustine's Intellectual Conversion: The journey from Platonism to Christianity, Cambridge 2009.

23 Plotinus, Enneaden, vertaald en ingeleid door R. Ferwerda, Budel 2005. 
ook dat dit aanraken geen handeling is die de ziel zelf tot stand brengt. Er is sprake van een 'licht worden', in vuur en vlam staan door een licht dat de ziel niet is. In deze passage hebben wij te maken met exact dezelfde drieslag als in de extase van Ostia: opklimming, eenwording en daarna terugval in het discursieve denken. Waarom is deze beschrijving dan belangrijk als achtergrond bij de extase van Ostia? Wat zegt het over 'bestemming'? Wellicht dit. De eerste twee 'verlatingsscènes' (Dido en Monica) stellen dat er een bestemming is die een goddelijk karakter, een goddelijke herkomst heeft. Wie die bestemming niet bereikt, staat schuldig, ook al heeft God die bestemming bepaald en niet de mens. Zo beschrijft Augustinus het dan ook als hij spreekt over het achterlaten van zijn moeder, als schuld. Dus het kennen van de bestemming, het raken aan het ware zijn, ondergaat een moralisering. De kenmogelijkheden dan wel onmogelijkheden worden teruggebracht tot een deugdenleer: als je het goede kent, dan moet je het ook doen. Dat Augustinus dat goede niet altijd heeft gedaan, daar zal hij zijn hele leven mee worstelen. Maar hij zal dus ook altijd meegaan in het transformeren van de ontologie (het goede) in een deugdenleer. Welnu, het bijzondere van deze passage is nu juist dat hier de moralisering voor één keer wordt weggelaten. Het is een schouwen dat zich 'zomaar' voordoet en niet valt terug te brengen tot eigen deugd. Dat maakt het belang van deze passage groot: er is een werkelijkheid buiten de moraal. In christelijke termen, er is een godsbeleving die zich afspeelt buiten de dichotomie van zonde en genade. Hermeneutisch gesproken dient deze passage ertoe om, terugverwijzend naar het achterlaten van Monica en Dido, een wereld te schetsen die als confessio eerder ontvankelijkheid beoogt dan schuldbelijdenis. Dan kan het zware beeld van Dido's dood en Augustinus' schuld juist buiten de wereld van schuld en genade geduid worden. Daarmee is deze scène het verdwijnpunt van de schrijver geworden. Er is een werkelijkheid geschetst die het subject van zichzelf berooft. Waarom is dat? Omdat en nu schakelt Augustinus gemakkelijk naar Stoïcijnse motieven - de bisschop twee begrippen wil laten uitkomen, dat van ordo en predestinatie. Die twee noties verbindt Augustinus sterk met elkaar door aan het einde van de verlatingsscène op te merken dat God een bepaalde orde van tevoren had bepaald en dat hij die ten uitvoer brengt. ${ }^{24}$ Waar het dus om gaat is een bepaalde bestemming bereiken die God als een ordo in het leven legt. ${ }^{25}$

24 Conf. V,9,17: faciebas ordine, quo praedestinaueras esse faciendum.

25 S.E. Thompson, 'What Goodness is: Order as the Imitation of Unity in Augustine', The Review of Metaphysics 65 (2012), 525-553; A.-I. Bouton-Touboulic, L'ordre chaché: La notion d'ordre chez saint Augustin, Paris 2004. 
Daartoe is het verhaal van deze extase nodig, juist om bestemming een andere lading te geven. Dan is het mogelijk te raken, niet aan God, maar aan het zijn zelf, het id ipsum, ${ }^{26}$ het hart van de ordo. De schrijver verdwijnt in de goddelijke ordening.

\section{Het christelijk perspectief - Dupont}

Dikwijls wordt naar de Ostia-ervaring verwezen als indicatie dat Augustinus zich in 386 (nog) niet tot een Paulinisch/Bijbels christendom had bekeerd, maar eerder tot een vorm van Neoplatoons christendom. Zijn beschrijving van de Ostia-extase vertoont immers gelijkenissen met het Neoplatoonse schema van de anabase, zoals hierboven geïllustreerd. Op literair niveau merken we echter dat Augustinus - niet expliciet maar eerder impliciet toch wijst op enkele specifiek christelijke eigenschappen van zijn ervaring te Ostia. Toen Augustinus zich nog niet bekeerd had tot het christendom, had hij immers een gelijkaardige religieuze ervaring beleefd in Milaan na het lezen van enkele boeken van de neoplatonisten (Confessiones VII,10,16; VII,17,23; VII,20,26). Deze neoplatonisten hadden Augustinus geleerd om zich af te keren van de wereld, om het geluk in het eigen innerlijk te zoeken en in dat innerlijke God te vinden. Er zijn overeenkomsten tussen de religieuze ervaring in Milaan en hier in Ostia: een afstandname van de uitwendige wereld, een inkeer in de ziel, een doorlopen van de verschillende niveaus van de werkelijkheid culminerend in een ontmoeten van het Goddelijke dat slechts een ogenblik duurt. Er zijn echter ook fundamentele verschillen. De eerste ervaring hielp hem om zich tot het christendom te bekeren, maar hij had zich op dat moment nog niet bekeerd. Het was met andere woorden misschien wel een ervaring van het hogere, maar het was zeker nog geen christelijke ervaring - althans, zo laat Augustinus ons impliciet verstaan. Augustinus had, zoals hij zelf schrijft, op dat moment niet de nodige christelijke kaders en vooral de christelijke gesteldheid (van nederigheid) om de hem geschonken ervaring volledig te begrijpen. Een fundamenteel verschil is dat hij de eerste ervaring alleen en op zichzelf beleefde, de tweede in gemeenschap met zijn moeder. De eerste ervaring toont dat Augustinus eigengereid was en dacht dat hij volledig op eigen kracht tot God gekomen was. Gaandeweg leert Augustinus ontdekken dat dit onmogelijk is, dat hiervoor genade nodig is. Daarom is het juist in de dialoog samen met zijn moeder dat hij ten volle God kan ervaren. Samen met de ander komt hij tot de

26 Conf. IX,10,24, maar ook IX,4,11 (2x). 
Ander. Augustinus vat deze eerste ervaring op, ten onrechte zoals hij later bekent, als een resultaat van zijn eigen denkarbeid en zodoende als een bewijs van zijn intellectuele superioriteit, als een bevestiging van zijn totale autonomie. Zijn tweede ervaring rekent hij volledig toe aan God, hij geeft zich vol vertrouwen over aan heteronomie.

In het vervolg van zijn beschrijving legt Augustinus meer precies de aard van zijn Godservaring uit. Reeds van bij het begin benadrukt hij wel dat het niet zo evident is dat de mens, een veranderlijk schepsel, tot een beleving van God, de onveranderlijke Schepper, kan komen: 'voorzover we daar ontvankelijk voor waren, richtten we onze gedachten toch op zoiets groots'. De mens is beperkt. De mens kan bijgevolg zelf niet op eigen kracht tot het goddelijke komen. Met andere woorden, de mens kan dit niet zonder de genade van God. Augustinus beschrijft hoe hij en zijn moeder in aanraking komen met de waarheid. Dat is niet iets wat ze louter met behulp van eigen capaciteiten verwezenlijkt hebben. Augustinus schrijft dat dat gesprek, dat zal uitmonden in de ervaring van de waarheid, van het begin plaatsvond 'in de tegenwoordigheid van de Waarheid' (IX,24) die God is. Vanaf het begin was God reeds aanwezig. Vanaf de aanvang was het eigenlijk een gesprek met drie. Meer nog, God als Waarheid en het Woord, was de basis die het voor Augustinus en Monica mogelijk maakte om waarachtig te kunnen spreken en om in dat gesprek God op het spoor te (kunnen) komen. Daarom noemt Augustinus God hier ook 'de bron van het leven', het levengevende begin van alles, kortom genade.

\section{Vergoddelijking? - Smalbrugge}

Zo zou dus de genade een centrale rol vervullen in deze passage. Maar is dat zo, bij dit begrip dat in de tekst überhaupt niet aanwezig is!? Of wordt dit nu juist gesteld omdat het moderne Augustinus-onderzoek genade eigenlijk altijd in een bepaald licht stelt? Namelijk door het te plaatsen in het kader van een dichotomie van een oorsprongszonde versus genade. Zo er immers sprake is van een continuüm in Augustinus' werk, stelt men, dan moet dat gezocht worden in zijn genadeleer. Maar die genade is inderdaad volstrekt geen stabiel begrip. Het begint met een Platoonse opvatting, aldus Philip Carey, waarin genade wordt verstaan als een innerlijke aanwezigheid van Gods hulp om de waarheid te vinden. ${ }^{27}$ Dat spoor wordt door Augustinus

27 Ph. Carey, Inner Grace: Augustine in the Tradition of Plato and Paul, Oxford 2008, hoofdstuk 1, 'Inner Help to Love', 8-21. 
niet verder doorgetrokken omdat hij stuit op het probleem van de wil. Wil de mens Gods hulp wel aanvaarden? Of is het eerder zo dat de wil niet in staat is te willen wat zij wil, c.q. dat zij tegelijkertijd iets wel en niet wil? Dat Paulinische spoor, ontleend aan Romeinen 7:15, maakt dat de genade voor Augustinus exclusief tot Gods handelen wordt bestempeld waar de mens geen enkele invloed op heeft. Niettemin, waar de wil faalt, en de mens afdwaalt van de waarheid, blijft dat wel volledig de menselijke schuld. Aangezien deze dwaling in Adam tot een definitieve menselijke werkelijkheid is geworden, is de basisconditie van de mens die van zonde en schuld. Zijn enige hoop is nog Gods genade. Zo zijn, vanaf Ad Simplicianum (ongeveer uit dezelfde tijd als de Confessiones 397/398), genade en schuld (c.q. zonde) een onafscheidbare twee-eenheid geworden en heeft genade een volstrekte moralisering ondergaan. Zij is geplaatst in het kader van een deficiënte deugdenleer. ${ }^{28}$ De enige relevante vraag blijft dan in welke mate een mens het goede kan doen; niet: in welke mate hij het goede kan bereiken of aanraken, zoals dat in de Platoonse traditie nog gold. Een 'goede' dat bij Plato als de hoogste werkelijkheid fungeerde en, net als het 'schone', niet gerealiseerd hoeft te worden middels deugden. Een a-moreel goed dus. Daar neemt Augustinus uitdrukkelijk afscheid van, allang voor de Pelagiaanse kwestie. Voor hem geldt de vraag 'hoe kan een mens het goede realiseren?' en zijn antwoord zal zijn dat dat alleen maar kan dankzij het geschenk van Gods genade. Genade is daarmee de kracht geworden die een mens uit zijn natuurlijke, post-lapsum, staat wegrukt. Het is niet meer het Licht dat zomaar op je valt, het is een bewust geschenk, als keuze, van God. Die lijn zal steeds sterker worden aangezet en in de Pelagiaanse controverse uitlopen op een harde aanscherping door Augustinus van de predestinatie. Dat in tegenstelling tot de ontwikkeling van de Oosterse theologie, waar een concept als deificatio een vitaal begrip blijft, als beschrijving van de dynamische band tussen God en mens. ${ }^{29}$ Het vreemde daarbij is dat ook het wetenschappelijk onderzoek naar de Augustijnse genadeleer heeft geleden onder Augustinus' latere opvatting van de genadeleer. Immers, waar genade als continuüm kon worden aangewezen, was in één klap ook het christelijk karakter van het werk veiliggesteld. Terwijl al sinds de jaren '50 het beroemde werk van Pierre Courcelle ${ }^{30}$ - duidelijk was gemaakt dat de

28 J. Wetzel, Augustine and the Limits of Virtue, Cambridge 1992.

29 D. Meconi, The One Christ: St. Augustine's Theology of Deification, Washington D.C. 2013. Sed contra, M. Smalbrugge, 'The Presence of the Absent, Augustine and Deification', in S. van Erp, K. Schelkens (red.), Conversion and the Church. The Challenge of Ecclesiastical Renewal, Leiden/Boston 2016, 27-38.

3 o Pierre Courcelle, Recherches sur les Confessions de saint Augustin, Paris 1968. 
tegenstelling Platoons of christelijk denker een anachronisme was. Wat duidelijk zou moeten zijn, is dat het begrip genade vele vaders heeft. Er zijn Platoonse, Neoplatoonse en Bijbelse bronnen. Die kunnen we niet goed meer onderscheiden en dat non sequitur is de enige wetenschappelijk acceptabele verklaring. Wie verder wil gaan dan deze aporie en toch per se een christelijke duiding aan het begrip genade wil geven, doet aan ideologisering, c.q. confessionalisering, van het wetenschappelijk onderzoek. Daarom is de passage die wij hebben belicht zo belangrijk. Zij toont aan dat Augustinus op onvermoede wijze met schuld tracht om te gaan. Namelijk door juist niet schuld aan genade te koppelen, maar door een staat van ontvankelijkheid te schetsten die veelal met genade wordt aangeduid. Hier wordt een condition humaine geschilderd waar niet schuld het kernbegrip is, maar ontvankelijkheid. De schrijver kan rusten, in God. ${ }^{31}$ Een God die aan gene zijde van genade en schuld bestaat.

\section{Bekerings-enthousiasme? - Dupont}

Eerder pleitte ik om continuïteit te zien in Augustinus' genade-denken. ${ }^{32}$ Deze claim impliceert dat de jongere Augustinus zich ook reeds bewust was van de menselijke beperkingen - die een alomvattende genade impliceren. De Ostia-extase presenteert, op het eerste gezicht, een probleem voor deze continuïteitsstellingname, daar ze lijkt te suggereren dat de mens reeds in dit leven - ofschoon kortstondig en onder bepaalde condities - tot een volledige godsontmoeting kan komen, wat haaks staat op een verstaan van de mens als intrinsiek beperkt vanwege de oorsprongszonde. Het is echter wel intrigerend vast te stellen dat Augustinus na de Confessiones nooit meer terugkomt op wat er in Ostia gebeurde, ofschoon hij nooit weigerachtig was om intieme details van zijn eigen leven en denken te delen. We weten dat Augustinus heel lang twijfels had over het aanvaarden van mirakels. Slechts laat in zijn leven, onder 'pastorale' druk van de immens populaire verering van martelaren in Noord-Afrika, aanvaardde hij ze, en steeds onder strikte voorwaarden. ${ }^{33}$ Dit zou eventueel de weigering of misschien

31 Conf. I,1,1.

32 'Continuity or Discontinuity in Augustine? Is There an "Early Augustine" and What Does He Think on Grace?' (Review Article of: C. Harrison, Rethinking Augustine's Early Theology: An Argument for Continuity, Oxford, 2006), Ars Disputandi 8 (2008) 67-79.

33 S. Lancel, 'La Tardive Acceptation du Miracle', in S. Lancel, Saint Augustin, Paris 1999, 648-658. 
zelfs schaamte van de oudere, meer bedaarde en intellectueel-reflectieve theoloog Augustinus verklaren om te praten over wat hij dan misschien beschouwde als het overdreven enthousiasme van een jonge bekeerling.

Een andere verklaring zou kunnen zijn dat Augustinus snel begreep dat zijn beschrijving van de Ostia-ervaring eigenlijk niet strookte met zijn eigen genadedoctrine. De Confessiones willen een les zijn over de relatie tussen God en de mens, over hoe God aanwezig is in het leven van de mens, over de werkzaamheid van Gods genade. Deze algemene interesse in genade is ook aanwezig wanneer Augustinus de gebeurtenissen te Ostia vertelt. Twee keer benadrukt Augustinus die genade in de zinnen waarmee hij zijn verslag van de gebeurtenissen te Ostia inleidt. Zijn moeder stond op het punt te sterven, echter alleen God wist wanneer ze ging sterven. De kennis van Monica's nakende dood ligt volledig in Gods handen, ligt buiten het bereik van de menselijke kennis. Het feit dat hij en zijn moeder alleen aan dat raam stonden, duidt hij eveneens aan als het resultaat van Gods voorzienigheid. God had er voor gezorgd dat zij, op dat moment en op die plaats, samen waren. God had met andere woorden de ervaring van moeder en zoon mogelijk gemaakt. Zowel de dood van zijn moeder als wat ze samen beleefden te Ostia legt hij volledig in de handen van God. Op deze wijze kunnen we stellen dat Augustinus' denken over de goddelijke genade en de menselijke beperktheid in nucleo reeds present zijn in de Confessiones als kader rond de Ostia-ervaring. De inhoud van dat kader - de Ostia-ervaring zelf, een ervaring van God - blijft echter een paradox binnen Augustinus' (latere) genade-denken, omdat zijn genadedoctrine de mogelijkheid van een dergelijke ervaring binnen dit leven in vraagstelt.

Bij de verdere ontwikkeling en verdieping van zijn oorsprongszondeleer, komt Augustinus tot de duidelijke stellingname dat omwille van de oorsprongszonde een totale ervaring van God in dit leven per definitie onmogelijk is. Denken we bijvoorbeeld maar aan zijn positionering in De Trinitate (399-420) dat een volledig begrip van God door de mens hier op aarde onmogelijk is als rechtstreeks (straf-)gevolg van Adams val. ${ }^{34}$ Deze claim vinden we regelmatig terug in Augustinus' geschriften voorafgaand aan de Confessiones. ${ }^{35}$ Ook horen we hiervan een krachtige echo in de Confessiones zelf wanneer Augustinus bekent dat Gods grootheid hem altijd overstijgt: Tu autem eras interior intimo meo et superior summo meo (III,11). Vooral vanaf 411, in het hoogoplopende debat met zijn 'pelagiaanse' tegenstanders bouwt Augustinus' zijn genade- en zondeleer op een heel

35 De ordine 2,44; 2,47; Contra Adimantum 40; De moribus eccl. Cath. 1,24. 
systematische wijze uit. Binnen dit anti-pelagiaans discours blijkt zijn eigen Ostia-ervaring een volstrekt Fremdkörper te zijn. Augustinus betoogt dat de volledige mensheid deelt in de eerste zonde, de schuld en de strafgevolgen die daaraan verbonden zijn. Eén van de blijvende effecten voor alle mensen is dat zij, zelfs na het doopsel, getekend zijn door onwetendheid en het voortdurend verlangen tot zonde (concupiscentia). Voorafgaand aan de val waren Adam en Eva vanzelfsprekend gericht op God, hadden gemakkelijk toegang tot hem, en deden probleemloos het goede. De val echter verbrak die onmiddellijke God-oriëntatie, en de mensheid is sindsdien, integendeel, automatisch geneigd tot het kwade. ${ }^{36}$ Vandaar kan de mens zonder Gods genade eigenlijk alleen maar zondigen. Bovendien is ten gevolge van de inherente infralapsaire menselijke onwetendheid en zondendrang een complete kennis of ervaring van God in dit aardse tranendal onmogelijk. Binnen dit perspectief betekent Augustinus' beschrijving van de Ostia-ervaring een contradictie met zijn eigen (anti-pelagiaanse) opvattingen over genade en oorsprongszonde. Dit zou kunnen verklaren waarom hij later in zijn leven zweeg over wat er te Ostia geschiedde, of althans op zijn minst over hoe hij dat op een bepaald moment zelf had ervaren en begrepen.

\section{Een 'Ostia' voor iedereen?}

Augustinus verhaalt een heel intieme ervaring die hij deelde met zijn moeder. Hij onthult een staat van genade die los staat van elke schuldvraag, maar die gaat over ontvankelijkheid voor het Licht. Waarom? Wellicht om dit aan te geven. In de tweede verlatingsscène was er sprake van aversio, een zich afkeren van zijn moeder, in aansluiting op de aversio van Aeneas. $\mathrm{Nu}$ is er sprake van een conversio. Niet in de zin van bekering, maar van gezamenlijk deelachtig worden aan een Licht dat mensen samenvoegt. Er is afscheid genomen van de moralisering van conversio/bekering, er is een andere grondtoon aangeslagen.

Het is duidelijk waarom de Ostia-extase zelden wordt geciteerd in de context van de studie van Augustinus' genadeleer:ze lijkt er een tegenspraak mee te vormen. Althans, zolang men vasthoudt aan de twee-eenheid schuld \& genade. Dit is wellicht juist de kiezel in de schoen van het onderzoek naar Augustinus' genadeleer. Precies omdat deze tekstpassage wat betreft 
genade de spanning genade-zonde-vrijheid niet opheft, de paradox laat bestaan, weerstand blijft bieden aan unificerende verklaringsmodellen, denken wij dat het heel waardevol is om de Ostia-extase te integreren in het genade-onderzoek. Het wijst ons immers de richting naar Augustinus' fundamentele genade-hermeneutiek. Althans, het maakt ons duidelijk dat een dergelijke hermeneutiek vaak de gevangene blijft van reeds voorliggende hermeneutische standpunten. Daarom verhindert deze passage ons om Augustinus en zijn genadedenken op te sluiten in een uniform systeem.

Net zoals Augustinus aangeeft fundamenteel het goddelijke niet te kunnen vasthouden - louter kort te kunnen aanraken - zo lijkt het ook te gaan met onze poging deze passage te onderzoeken: via onze analyse van de tekstuele elementen stijgen we op naar een poging de inhoud van deze elementen te begrijpen, en realiseren we dat genade de katalysator van de Ostia-ervaring - tekstueel en inhoudelijk - is. Tot een volledig begrip van die genade op basis van Confessiones IX,10,23-12,29 komen we echter niet, wellicht nooit. Aangekomen op dit punt, verdwijnt niet alleen de auteur, maar ook de lezer.

\section{About the Authors}

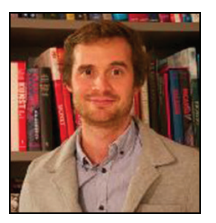

Anthony Dupont is Onderzoeksprofessor Christelijke Oudheid aan de Faculteit Theologie en Religiewetenschappen van de Katholieke Universiteit Leuven, SintMichielsstraat 4 bus 3101, BE-300o Leuven, België.

E-mail: anthony.dupont@kuleuven.be

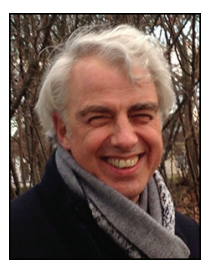

Matthias Smalbrugge is Professor Europese Cultuur en Christendom aan de Faculteit Godgeleerdheid van de Vrije Universiteit Amsterdam, De Boelelaan 1105, 1081 HV Amsterdam, Nederland.

E-mail: m.a.smalbrugge@vu.nl 
